\title{
The Evolving Security Landscape: Citizens' Perceptions of Feminism as an Emerging Security Threat
}

\author{
Eva-Karin Olsson Gardell ${ }^{1}$ D $\cdot$ Charlotte Wagnsson $^{1} \cdot$ Claes Wallenius $^{1}$
}

Received: 13 August 2021 / Accepted: 31 December 2021 / Published online: 21 February 2022

(C) The Author(s) 2022

\begin{abstract}
In this article we explore how Swedish citizens perceive security threats, and how threat perceptions overlap with ideology, trust and demographics. The results show that concerns over security threats are foremost connected to an authoritarian outlook. In addition, four typical groups of security orientations were identified. On the one end of the spectrum, we found one group with anti-immigrant, anti-feminist and anti-egalitarian opinions and low confidence in media and institutions. At the other end, we identified a group dominated by women with university degrees, who believe in egalitarian tolerance and display trust in societal institutions. Even though the findings are in line with previous research on the radical right globally, we were intrigued by the existence of a clearly defined group of respondents that oppose feminism to the extent that it is even seen as a security threat. This is particularly striking given that Sweden is thought of as one of the most equal countries in the world, with a government pursuing a feminist foreign policy.
\end{abstract}

Keywords Security $\cdot$ Feminism $\cdot$ Right-wing

Feminism and gender concerns are increasingly influencing foreign and security policies. A feminist approach to foreign policy places emphasis on care and relationships and is focused on the need for listening and inclusion (Aggestam et al. 2018; Robinson, 2021). Sweden and Canada have embraced the feminist approach wholeheartedly in adopting an explicitly feminist foreign policy. The fact that foreign and security policies can be understood as gendered means that they can also be masculinized. According to Agius and Edenborg (2019), Swedish and Russian foreign policies are imbued with gendered power relations; in one corner there is, Sweden's progressive and feminist foreign and security policy, and in the other corner, Russia's masculinist framed policy. Based on Sweden's high profile, it is intriguing to explore attitudes towards feminism and security. Previous research demonstrates that

Eva-Karin Olsson Gardell eva-karin.gardell@fhs.se

1 Swedish Defence University, Drottning Kristinas Väg 37, 11593 Stockholm, Karlstad, Sweden 
the success of feminist policies, in general, tends to create various forms of backlashes (for an overview see Flood et al. 2021). Has the strong political promotion of feminism in the security policy domain evoked any reactions in Sweden, perhaps even a backlash?

There is a lack of research exploring feminism in relation to perceptions amongst the general public on national security. This is somewhat surprising since threats to national security are powerful rhetorical emotional tools, which can effectively be turned against feminism and women's rights. Gendered perceptions should be understood, at least partly, against the backdrop of the radical right movement. The notion of security is at the very heart of that movement and the political agenda is often formed in response to 'elitist' security agendas, accusing the elite of not understanding, or acting upon, threats to the 'people'. The rhetorical use of fear and threats is effective in making citizens long for order and security, which increases public preferences for authoritarian policies (Feldman, 2003; Hetherington and Suhay 2011; Huddy et al. 2002; Merolla and Zeichmeister 2009; Perrin 2005).

The global radical right movement is not altogether easy to define, due to its various national political expressions. In general, it is built upon a foundation of ethnonationalism, with the aim of making the nation ethnically homogenous. Moreover, there is a wish to return to traditional values, including law and order. There is also resistance towards internationalization and a mistrust of the establishment, including news media (Rydgren 2018, p. 2). Traditionally, the radical right movement was created based on the notion of "us" and "them", where the traditional "them" has been concerned with race, ethnicity, and immigration (Wodak 2015). In the last decade, scholars have begun to explore the intersection between race and other outgroups, such as women and LBTQ-persons (Agius et al. 2020; Innes et al. 2021). In being framed as a counter-movement to traditional values, feminism is portrayed as a threat to the family, society, and nation (Grzebalska and Petô 2018; Verloo and Paternotte, 2018). In general, threat perceptions are built upon anti-global, antidiversity, and anti-immigration. These are essential components in the narratives of the radical right (Keskinen, 2013; Mullinari and Neergard 2014; Norocel et al. 2020).

The connection between radical right and feminism is intricate. One way of understanding it is through the notion of 'femonationalism', which highlights how feminism is used by xenophobic actors as a reason for attacking migrants for not adhering to progressive liberal Western ideals related to feminism and women's rights (Farris, 2017). It is also important to note that even though anti-feminism is primarily associated with radical right parties, it has also emerged as a new grassroots movement in various countries across the globe (Wojczewski 2020). In this regard, anti-feminism cannot be reduced to a simple backlash but is rather a new ideological political force that combines gender conservatism with a critique of neoliberalism and globalization (Korolczuk and Graff 2018).

In this study, we explore average Swedes' threat perceptions and how these relate to ideological preferences, trust (in the media, authorities, and politicians), and demographics. We examine perceptions of antagonist threats, which refers to actors or phenomena that appear as negative 'others', because of their potential for destabilizing, or in other ways harming, the state. We explore perceptions of "established" 
antagonistic threats, such as military threats, as well as "new" threats, such as migration and feminism, which have emerged alongside the rise of populism and right-wing parties.

The following research questions were asked:

(1) Which security threats do the Swedish population identify?

(2) How do these threat perceptions correlate with political ideology (including authoritarian right-wing attitudes) and trust (in the media, politicians, and authorities)?

(3) How can these threat perceptions be explained based on demographics?

(4) On a group level, what security orientations can be identified in the population, based on threat perceptions, ideological orientation, trust, and demographics?

\section{The Swedish Case}

Traditionally, Sweden has been understood as a progressive feminist state, standing up for women's rights both at home and globally. Feminism is an explicit component of the Swedish "feminist foreign policy" (Government Offices of Sweden/ Ministry for Foreign Affairs 2018, p. 6). For long, Sweden did not experience an anti-feminist mobilization on the grass-root level, but that changed in the mid-2000s (Johansson, 2014). For example, an online antifeminist counter-public has emerged in Sweden, driven by highly educated men, who-empowered by anonymity-have created viable and strong antifeminist online networks (Holm 2020). Another example of an anti-feminist online publics is global incel forums, driven and dominated by hatred towards women. A high share of participants in these forums are from Sweden (Fernquist et al. 2020). In Sweden, there is also a growing radical right movement with a strong anti-feminist message. The Swedish Security Police warns of increasing support for the pro-violence alt-right movement driven by racism, antimigration, conspiracy theories, and anti-feminism (Säkerhetspolisen 2020).

Despite Sweden's long history of being a consensus-driven democracy, public opinion divergence has increased, at least in some policy areas. One such salient issue is immigration. For a long time, Sweden was seen as a deviant case in the European context, being one of the few countries that did not have representation by a radical right party in the Parliament (Rydgren, 2002). However, that changed in 2010, when the Sweden Democrats (SD) entered Parliament. Today, the party fluctuates between being the second and third-largest party. It has mainly focused on the migration issue. This has contributed to migration becoming a highly polarized issue in the Swedish political debate during the last decade (Hovden and Mjelde 2019; Bergström et al. 2017). With the entry of the party, the appliance of the GAL/ TAN (Green/Alternative/Libertarian - Traditional/Authoritarian/Nationalist) divisions of political conflicts become relevant for understanding cleavages in Swedish politics (Demker and Odmalm, 2021).

$\mathrm{SD}$ is an interesting case, having to balance radical right attitudes in a national context where gender equality is politically established to the extent that it has even 
become part of national identity (Towns et al. 2014). SD argues for a traditional understanding of men and women, depicting men as breadwinners and women as primarily responsible for running the household (Norocel et al. 2020; Towns et al., 2014). According to Sager and Mulinari (2018), SD policies regarding feminism have been centered on the notion of safety, where feminism, and women embodying feminist opinions, have been seen as a threat to safety and national cohesion. At the very same time, women's rights and feminism have in relation to migrants, especially Muslims, have been framed as being under threat and their argumention follows the line of 'Femonationalism'. This duality has also been noted amongst SD voters, who tend to embrace gender equality, when being compared to what is depicted as Muslim values, while they are critical of feminism. In this logic, the nation is threatened by Islam from the outside, and by feminists from the inside (Mulinari and Neergard 2014).

Even though there has been a general tendency for the radical right movement to hold anti-feminist opinions, the picture is multifaceted. Many European radical right parties, including SD, have in fact started to embrace progressive Western liberal ideas such as feminism and gay rights. In doing so, they place the threat from migrants-Muslims in particular -at the forefront, arguing that Western values and nations should be defended and that the defense should include all citizens regardless of gender and personal preferences (Duina and Carson, 2020). On the other hand, Spierings et al (2017) argue that, even if radical right parties change their rhetoric, few of their voters are attracted by such opinions.

Previous research shows that Swedish citizens' political opinions can be explained by a range of factors, for example, place of residence (Andersson, et al. 2017) and educational level (Vestin 2017). Gender, educational level, and age have proven to be important demographic factors for explaining differences in views on immigration (Demker, 2017), whereas age and — to some extent—gender account for differences in views on defense spending (Berndtsson, et al. 2017). When it comes to security issues, previous research shows that gender often explains differences, where studies have shown that women are more likely to fear crime (Gustafsod 1998), terrorism (Huddy et al. 2005), war (Eichenberg, 2019) and their personal safety (Eichenberg et al. 2021). In a study on Swedish citizens' perceivions of military threats, terrorism, and crime, Wagnsson et al. (2020) show that differences in age and gender are the main explanatory variables. Based on previous research, we explore the impact of the following demographic variables: gender, age, country of birth, and education.

\section{Method}

\subsection{Measures}

We base the study at hand on a questionnaire exploring security perceptions from a broad perspective, ranging from 'traditional' topics related to military threats and terrorism to less evident 'others' such as repressive views towards people like migrants, LGBT persons or feminists. 
Due to the lack of established measures or scales, the questionnaire is self-made. To a large extent, the survey is built on a focus group study exploring Swedish citizens' views on an array of security policy issues and their solutions. The focus groups were constructed based on conversations in eight focus groups, with an average of seven respondents in each one. The respondents in the focus groups were carefully selected to mirror a diversity of the Swedish population (for more details see Wagnsson et al. 2020). It should thus be noted that feminism as a threat did not emerge from the focus groups, but came up as a free text answer in another survey on security perceptions conducted by the authors (for details see Wagnsson et al. 2020). Several respondents stated in their free-text answers that feminists or Sweden's feminist foreign policy constitute a security threat.

In conducting the survey at hand, we focus on security threats and measures to deal with these threats based on the focus group discussions and the free text answers. In addition, we added questions related to values (both derived from the GAL/TAN scale as well as from the traditional left/right scale), and questions related to trust in media, authorities, and politicians. Moreover, we included questions related to media use.

The questionnaire was designed to measure the following variables:

- Security perceptions: Opinions on defense, crisis and security issues included concerns, attitude to national threats (e.g. foreign powers, terrorism, migration, Islam, intolerance, lack of common values), and attitude to how to cope with national threats

- General ideological orientation was measured through items on both the left/ right dimension and the GAL/TAN (e.g. attitude to migration levels, LGBT rights, and multiculturalism).

- Confidence and trust in politicians, authorities, and media

- Demographic data included gender, age, residence, country of birth, and education.

- Security orientations: Groups with certain orientations based on threat perceptions, ideology, trust, and demographics

\subsection{Respondents}

A strength of the study is the large sample of 3000 respondents. Still, some groups may be under-or overrepresented. One clearly underrepresented group is the foreign-born one. In the sample, $6 \%$ are foreign-born, while they constitute $18 \%$ of the general population (Statistics Sweden). ${ }^{1}$ The reason for the underrepresentation maybe a lack of language skills or lack of experience in Swedish society. An overrepresented group is those with a higher educational level. In the sample, $40 \%$ have at least a three-year university education. The corresponding figure in the general population is $27 \%$ (Statistics Sweden). Finally, pensioners are overrepresented.

\footnotetext{
1 All population percentages are taken from Statistics Sweden's website (www.scb.se).
} 
The cohorts aged between 65 and 75 years are somewhat larger in the sample than the younger cohorts. This pattern is not seen in the general population, where the cohorts older than 55 years are smaller than the younger cohorts (Statistics Sweden). One reason for their overrepresentation maybe that pensioners have more time to respond to questionnaires.

\subsection{Procedures and Analysis}

The survey was conducted as a web survey. The data collection was done in collaboration with Kantar/SIFO, a company in the field of public opinion and marketing research. The survey was done using a web panel with over 100000 respondents. The panel consists of randomly recruited persons, from 16 years of age and older, and is representative of Internet users in Sweden. The data collection was conducted for two weeks in June of 2018. 3000 respondents filled in the questionnaire. The survey stayed open until that number had been reached, after which new potential respondents were invited to participate during that period. The participation rate was $37 \%$ which was calculated by looking at the proportion of panelists who received the survey and also answered it before it closed.

In the analysis, we explored how the indexes correlated. This exercise was invalue in exposing interesting nuances in relation to security perceptions, i.e. how general ideological orientation and level of trust (in the media, politicians, and authorities) correlated with security perceptions. After that, we took a closer look at demographics, i.e. on how the perceptions identified corresponded with demographic factors (gender, age, and education). Finally, we performed cluster analysis, looking into indexes, and demographics in order to identify groups with diverging security orientations.

The indexes were designed using factor analyses of the various blocks of questions (principal components with varimax rotation). The index's reliability was measured by Cronbach's alpha. Items that reduced the reliability were excluded from the indexes. The relationship between the indexes was studied by correlation analysis (Pearson bivariate). The difference between subgroups was mapped via t-test (independent samples) or variance analysis (one-way ANOVA). Survey questions that did not correlate with other items were omitted from the analysis. One such question is the fear of terrorism. It should also be noted that the index Feminism concerns is weaker than the other indexes since it is formed with only two items. Classification into clusters was done using a cluster analysis (k-means). The cluster analysis was done on the multi-item indexes that were constructed with the factor analysis as the basis. Terrorism was included in the cluster analysis in one single item. 


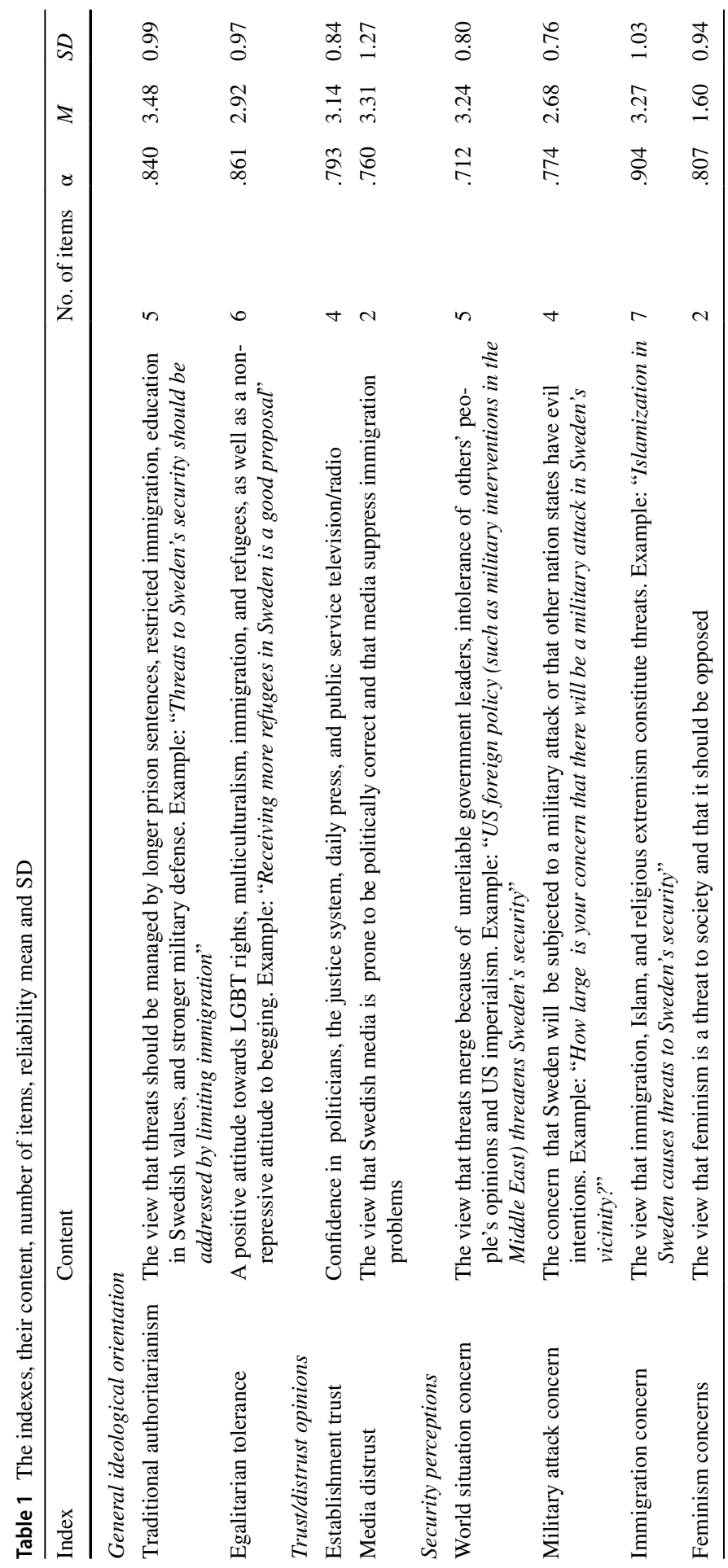




\section{Results}

\subsection{Indexing Security Perceptions and Opinions}

An exploratory factor analysis was performed in order to form indexes related to perceptions of security threats. It resulted in eight indexes with satisfying internal reliability $(\alpha>0.70)$ (see Table 1$)$. The indexes are presented below:

As presented in the table above, three types of indexes were identified in the empirical material, related to ideology, trust, and security perceptions.

The two ideologically-oriented indexes were named Traditional authoritarianism and Egalitarian tolerance. Traditional authoritarianism denotes a high inclination towards handling threats to Swedish security by taking a stronger stance towards antagonistic actors, longer and harder prison sentences, restriction of immigration, education in Swedish values, and strengthening of defense capability and defense budget. Egalitarian tolerance denotes a high inclination towards strengthening LGBT rights, multiculturalism, labor immigration, refugee reception, and a reluctance to introduce a ban on begging. The two ideologically orientated indexes have a strong negative correlation. The respondents either score high in Traditional authoritarianism or high in Egalitarian tolerance, not in both. It should be noted that the survey included questions that were aimed at capturing right/left positions on economic issues (privatization, government spending, etc.). These questions did not reach satisfying reliability in terms of indexing. As a result, our findings indicate that security orientations are better understood using ideological measurements of values, rather than by using a traditional left/right scale.

Next, we found two indexes related to trust and distrust in politicians, authorities, and the media. These indexes were mutually exclusive. We also identified four security indexes. The first index group consists of people who score high on fear of US foreign policy, unreliable leaders, men as leaders, and intolerancedifferent of opinions. The second index group scored high in fear of a military attack in Sweden's neighborhood and Russian foreign policy. The third index relates to religious extremism, islamization, fragmentation of Swedish values, and immigrants. The fourth index relates to feminism where there was a correlation between people who saw feminism as a threat and those who thought that fighting feminism would increase Sweden's security.

On a general level, the findings emphasize the connection between ideology and views on national security. Thus, it is not a traditional left/right support that seems to drive national security preferences but rather values measured by the GAL/TAN scale.

\subsection{Correlation between Security Orientations Indexes, Ideology, and Trust}

Next, we explore how the indexes identified above correlated, i.e. the relations between the security perceptions, ideological orientation, and trust and distrust will be explored (Table 2). 


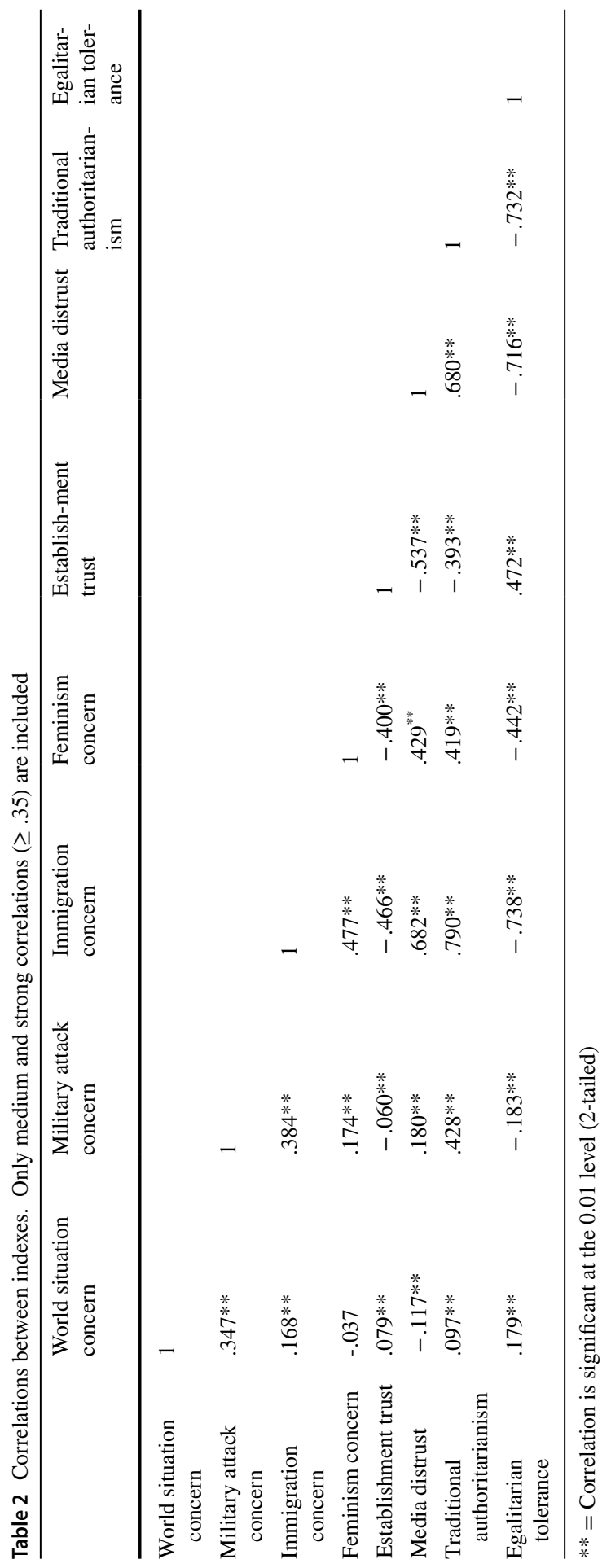


As shown in the table, Traditional authoritarianism correlates with World situation concern, Military attack concern, Immigration concern, and Feminism concern. People with this orientation are concerned with security in general, both with new and traditional threats. The correlation is strongest between Traditional authoritarianism, Immigration concern, and Media distrust, and negatively correlated with Establishment trust. Furthermore, Traditional authoritarianism also correlates with Military attack concern and Feminism concern to similar degrees. What we know from previous research is that a conservative outlook correlates with pro-militarism in general (Wagner et al, 2018). As accounted for in the introduction of the article, authoritarianism and right-wing parties tend to view immigrants as threats and to have a strong anti-elite and anti-feminism orientation, where established media is seen as an extension of the elite. Opposition to immigration is usually the strongest reason underpinning support for the radical right (Spierings and Zaslove, 2015). We found the correlation with feminism as a threat somewhat unforeseen, given Sweden's traditional and official feminist orientation, and that the issue has not been politicized in the public debate.

Looking at the other ideological index, Egalitarian tolerance, we can see that it only correlates with Establishment trust and to some extent World situation concern. The index is by and large opposite mirror of Traditional authoritarianism, and the strongest negative correlations can be seen when it comes to Immigration concern and Media distrust. In this regard, we can conclude that people with this orientation do not primarily understand the world in terms of threats and securities, but rather emphasize the role of values related to diversity and human rights, which directly opposes the threats depicted by the Traditional authoritarianism worldview. The threat that they do acknowledge is caused by US foreign policy and unpredictable (male) leaders who wage war.

\subsection{How Indexes Correlate with Demographics}

In this section, we explore how the indexes correlated with educational level, age, and gender (Table 3).

When it comes to educational level, the table shows that the group that have a university degree as the highest completed educational level is significantly more characterized by Egalitarian tolerance and Establishment trust and less by Immigration concern, Traditional authoritarianism, Media distrust and Feminism concern. That is, citizens with university degrees worry less about immigration and feminism, whereas there is no difference between citizens with or without university degrees when it comes to Military attacks and World situation concern. There were no significant differences for the other indexes.

Regarding age, we can see that the group above the age of 50 has significantly more of, Traditional authoritarianism while the group under 50 has more Egalitarian tolerance. Respondents over 50 are also more worried about immigration. There were smaller or non-significant differences for the other indexes.

When it comes to gender, we can see that men have somewhat more Immigration concern, Media distrust and Feminism concern, while women have more Military 


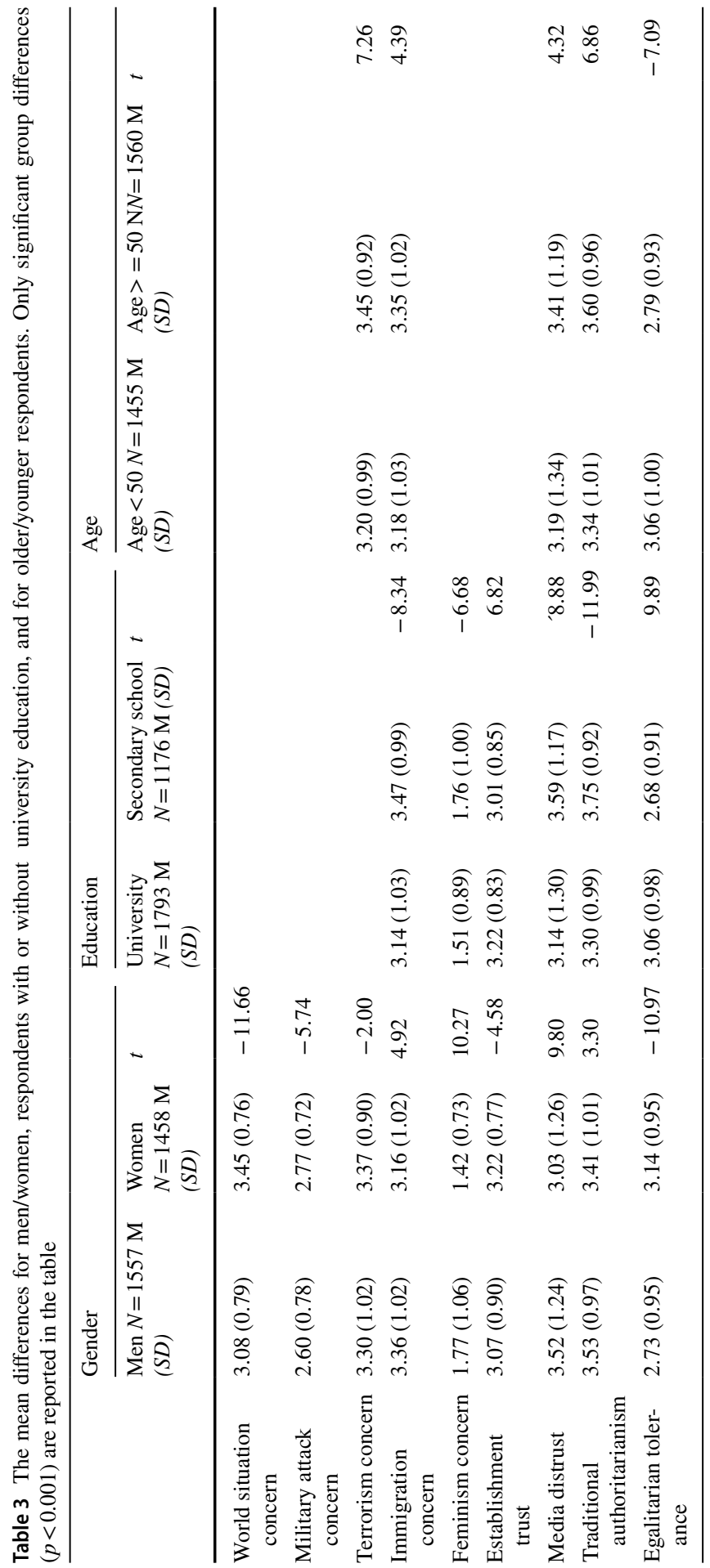


attack concern, World situation concern, Establishment trust, and Egalitarian tolerance. This confirms previous research stating that women are less inclined to fear immigration (Demker, 2017), and more inclined to fear war (Eichenberg, 2019) but at the same, they are, less in favor of the use of military force (Feinstein 2017; Lizotte 2019). These findings are also in line with previous research stating that women tend to be more supportive of government efforts to protect racial and ethnic minorities (1994).

Concerning Feminism concern, one would expect that it is exclusively men who see feminism as a threat. Men are in clear majority and there is a significant gender difference (Pearson Chi-Square 101,790; $p>0.000$ ). However, even some women worry about feminism. While 12 percent of the men agreed with the statement that feminism is a threat to Swedish security, only four percent of the women did. In summary, the results show that women are less inclined to embrace threats perceptions related to immigrants and feminism, which are generally favored by the radical right and populist parties. It can be noted that the dominance of men among radical right voters is a consistent finding across national contexts (Coffée, 2018).

\subsection{Identifying Security Orientations}

Finally, we conducted a cluster analysis in order to find groups with typical security orientations (Table 4).

In the cluster analysis. we identified four groups with the following characteristics in relation to each other:

1. "Radical-Rightists": This group holds anti-immigration, anti-feminist and antiegalitarian opinions. They are concerned about terrorism and have low confidence in media and established institutions. They are relatively more active online.

2. "Conservatives": This group includes more pensioners who live far from universities in smaller towns or rural areas. They are worried about immigration but also about terrorism, traditional military threats, and the world situation. They do not show distrust in media and established institutions and do not regard feminism as a threat.

3. "The Averages": This group is in-between the other groups on all variables. On most variables, it has groups 1 and 2 on one side and group 4 on the other. This group can be regarded as consisting of "The average Joe/Jane".

4. "Urban Multiculturalists": This group includes many educated women living in university areas. They are less worried about terrorism, immigration, or feminism and score high on Egalitarian tolerance. They trust the institutions and the media. They are more active online.

The cluster analysis highlights the fact that the conservative anti-immigration group actually consists of two groups: one is more radical, "radical-rightists" and one is more traditional conservative, "conservatives". These two groups differ concerning feminism. "Conservatives" do not perceive feminism as a threat to the same 


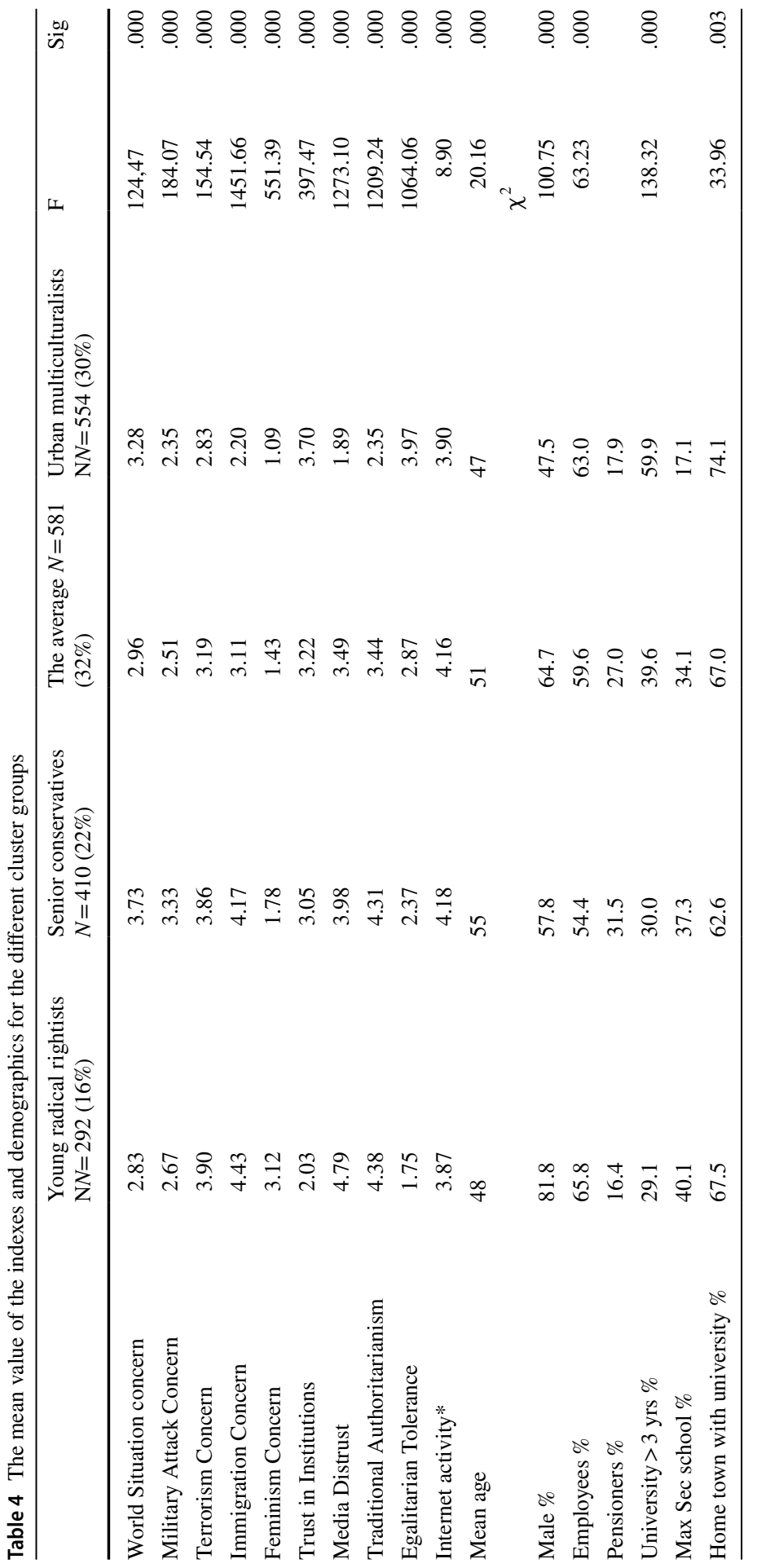


extent as the "radical-rightists". Moreover, even though both groups are concerned about immigration, the "radical rightists" see immigration as a security threat to a larger extent than "conservatives" do. "Conservatives" are also more worried about traditional security threats and have more trust in media and authorities compared to the "radical-rightists". The connection between populist radical right groups and Russia has been debated recently (Weiss 2020; Helmus et al. 2018; Butt and Bayman 2020). We can conclude that military attack concern, which are dominated by views of Russian foreign policy as a threat, is stronger amongst "conservatives" compared to the "radical-rightists". Finally, we also identified a group that worry less about the security threats identified in the study at hand, and that group is, university-educated women.

\section{Discussion}

The empirical section explored how citizens perceive security threats, how these perceptions intersect, and how they relate to ideology, trust, and demographics. We started out by identifying indexes of security perceptions, which show how perceptions are combined. We found four such indexes. The three strongest indexes concern Russian foreign policy and the risk of a military attack; US foreign policy and the risk of (male) unpredictable world leaders; and finally the risk of immigrants, religious extremism, and the threat to traditional Swedish values. As a two-item index, feminism as a threat to security was identified. What stands out is that perceptions regarding immigration, and Islam emerge as a clearly salient set of opinions amongst Swedish citizens. These findings are in line with recent political developments in Sweden and the rise of the Sweden Democrats party. It is interesting to note that feminism emerges as a security threat in the survey. Potential implications of this finding will be discussed further below.

From the material we also identified two ideological and value-driven indexes, Traditional authoritarianism and Egalitarian tolerance and two indexes about trust and mistrust in the media and authorities. We could see that Traditional authoritarianism is an index that correlates with all security perceptions, as well as with Media distrust and negatively with Trust in authorities. This finding corresponds with previous research on radical right voters who oppose immigrants and feminism and have a strong anti-elite orientation. These perceptions are interesting since they break with what is considered to be the Swedish typical national features, such as trust in politicians, authorities, and news media (Martinsson and Andersson 2019). Previous research tells us that there is a link between perceptions of feminism and ideological orientation were those individuals who score high in authoritarianism tend to embrace traditional social norms (e.g. Campbell and Erzeel 2018). Since feminism challenges those norms, it is not surprising that it has emerged as a threat. Based on the empirics, it is evident that threat perceptions no longer solely include traditional military threats, but that also involve 'internal others', such as migrants and feminism.

When it comes to demography, we can see that gender and educational level are the factors most strongly related to a person's security perceptions. The tendency 
is that working-class men dominate the authoritarian anti-immigration side, while women who have higher education dominate the egalitarian side. Regarding this, our findings are consistent with previous research on the radical right stating that it is mostly men that sympathize with such opinions. Moreover, women tend to be more concerned about war in general than men (Eichenberg 2019). In addition, women tend to be less supportive of "hawkish" measures regarding the use of military force (Brooks and Valentino 2011; Eichenberg 2003; Eichenberg and Read 2016).

Based on cluster analysis, four groups were identified." Radical-Rightists", "Conservatives"," The Averages", and"Urban Multiculturalists". The analysis shows that people with authoritarian anti-immigration views consist of two groups, where one is generally more radical and where respondents also perceive feminism as a security threat. The other group also worries about immigration, but score relatively high on trust and tolerance. The group with a more traditional conservative outlook is far less worried about feminism as compared to the more radical group. Conservatives are in fact the ones that worries the most about traditional security threats, including both Russia and US foreign policies and the risk of military violence.

The analysis reveals two groups with strongly opposing opinions, The Urban Multiculturalists, and The Radical-Rightists. The latter group has strong anti-egalitarian and anti-feminist attitudes, whereas the former advocates LGBT rights, multiculturalism, and immigrant reception. Both groups were also relatively more active online. The fact that they strongly oppose one another can be explained by the fact that the two groups share a superficial closeness when it comes to their criticism of economic liberalism and globalization. This makes them clash the hardest over gender equality, where they hold in essence diametrically opposing opinions (Lombardo and Kantola 2019). Therefore, they are likely to attract a fair share of media attention, fitting into the media dramaturgy centered on conflict further polarizing feminism as an issue.

The politicization of immigrants has been pushed onto the agendas of Swedish established political parties by a highly polarized public opinion and the fastgrowing nationalistic political party Sweden Democrats. The threat of feminism has not yet been subjected to mainstream media- and political debates. On the contrary, there is an official consensus that equality between men and women is crucial and should be encouraged, even though established political parties vary in terms of how much weight they give to the issue. However, if anti-feminism will follows the pattern seen previously when it comes to migration, we can expect that politicization of feminism, driven by radical and populist movements, will be picked up by other political parties and consequently spill over into the political mainstream field (Krzyżanowski 2018).

A limitation of this study is that the survey did not allow for respondents to elaborate on their answers, and therefore we are not able to say anything regarding in what way, and why, feminism is perceived as a threat to national security. One explanation could be that feminism is simply perceived as an expression of elite values, and therefore opposed by the respondents. In line with this explanation, it is mostly the values and norms underpinning, and associated with, feminism 
that are considered as threatening. However, it could also well be that respondents share the views promoted by spokespersons for the radical right movement, arguing that Sweden's foreign and security policy is infiltrated by a "pathological feminism", which makes the nation unable to defend and fight for itself, only to be left with the 'female' response of surrendering to and pleasing foreign powers (Nilsson 2019).

Finally, it is somewhat surprising to find a clearly defined group of Swedish respondents who oppose feminism to the extent that they percieve it as a security threat. This is particularly striking given that Sweden is considered to be one of the most equal countries in the world, with a government pursuing a feminist foreign policy. On the other hand, it could also be seen as an expected backlash given the high feminism profile Sweden wants to hold, in general, and of the Swedish foreign policy in particular. Despite awareness of a growing popular anti-feminist movement, most studies on anti-genderism have been done on rightwing parties and various subgroups such as incel-groups. Our findings stress the importance of examining attitudes among the general public. This is particularly relevant in a time when politics is increasingly driven by feelings of threats and insecurities, aimed at evoking emotional engagement, often playing the card of various in and out-groups. Our findings underline that more research is needed on how and why feminism is perceived as a source of insecurity amongst the general public. We encourage future research to provide a deeper understanding of the phenomenon and to elaborate on how such perceptions can be addressed and mitigated.

\section{Appendix I}

See Tables 5. 6 and 7.

Table 5 The differences between respondents with secondary (or elementary) school respectively university education as highest level completed

\begin{tabular}{lllrl}
\hline & $\begin{array}{l}\text { University } \\
\mathrm{N}=1793\end{array}$ & $\begin{array}{l}\text { Secondary school } \\
\mathrm{N}=1176\end{array}$ & $t$ & $p$ \\
\hline Immigration concern & 3.14 & 3.47 & -8.34 & .000 \\
Feminism concern & 1.51 & 1.76 & -6.68 & .000 \\
Establishment trust & 3.22 & 3.01 & 6.82 & .000 \\
Media distrust & 3.14 & 3.59 & 8.88 & .000 \\
Traditional authoritarianism & 3.30 & 3.75 & -11.99 & .000 \\
Egalitarian tolerance & 3.06 & 2.68 & 9.89 & .000 \\
\hline
\end{tabular}


Table 6 The differences between respondents above respectively under the age of 50

\begin{tabular}{lllll}
\hline & Age $<50 \mathrm{~N}=1455$ & Age $>=50 \mathrm{~N}=1560$ & $t$ & $p$ \\
\hline World situation concern & 3.19 & 3.29 & 3.07 & .002 \\
Military attack concern & 2.64 & 2.71 & 2.52 & .012 \\
Immigration concern & 3.18 & 3.35 & 4.39 & .000 \\
Establishment trust & 3.10 & 3.18 & 2.61 & .009 \\
Media distrust & 3.19 & 3.41 & 4.32 & .000 \\
Traditional authoritarianism & 3.34 & 3.60 & 6.86 & .000 \\
Egalitarian tolerance & 3.06 & 2.79 & -7.09 & .000 \\
\hline
\end{tabular}

Table 7 The differences between men and women

\begin{tabular}{llllr}
\hline & M Men N=1557 & $\begin{array}{l}\text { M Women } \\
\text { N=1458 }\end{array}$ & $t$ & $p$ \\
\hline World situation concern & 3.08 & 3.45 & -11.66 & .000 \\
Military attack concern & 2.60 & 2.77 & -5.74 & .000 \\
Immigration concern & 3.36 & 3.16 & 4.92 & .000 \\
Feminism concern & 1.77 & 1.42 & 10.27 & .000 \\
Establishment trust & 3.07 & 3.22 & -4.58 & .000 \\
Media distrust & 3.52 & 3.03 & 9.80 & .000 \\
Traditional authoritarianism & 3.53 & 3.41 & 3.30 & .000 \\
Egalitarian tolerance & 2.73 & 3.14 & -10.97 & .000 \\
\hline
\end{tabular}

Author contributions All authors contributed to the study's conception and design. Material preparation, data collection, and analysis were performed by EKG, CW, and CW. The first draft of the manuscript was written by EKG and all authors commented on previous versions of the manuscript. All authors read and approved the final manuscript.

Funding Own university.

Data Availability On request.

\section{Declarations}

Conflict of interest Author declares that they have no conflict of interest.

Open Access This article is licensed under a Creative Commons Attribution 4.0 International License, which permits use, sharing, adaptation, distribution and reproduction in any medium or format, as long as you give appropriate credit to the original author(s) and the source, provide a link to the Creative Commons licence, and indicate if changes were made. The images or other third party material in this article are included in the article's Creative Commons licence, unless indicated otherwise in a credit line to the material. If material is not included in the article's Creative Commons licence and your intended use is not permitted by statutory regulation or exceeds the permitted use, you will need to obtain permission directly from the copyright holder. To view a copy of this licence, visit http://creativecommons.org/licen ses/by/4.0/. 


\section{References}

Aggestam K, Bergman Rosamond A, Kronsell A (2019) Theorising feminist foreign policy. Int Relat 33(1):23-39

Agius C, Edenborg E (2019) Gendered bordering practices in Swedish and Russian foreign and security policy. Polit Geogr 71:56-66

Agius C, Rosamond AB, Kinnvall C (2020) Populism, ontological insecurity and gendered nationalism: masculinity, climate denial and Covid-19. Pol Relig Ideol 21(4):432-450

Andersson U, Ohlsson J, Oscarsson H and Oskarson M. (2017). Larmar och gör sig till. In: Andersson, A, Ohlsson, J, Oscarsson, $\mathrm{H}$ and Oskarson, M (eds) Larmar och gör sig till. SOM-undersökningen 2017. SOM-rapport nr 70. Göteborg: SOM-institutet

Bergström A, Demker M, Jansson D, Ohlsson J and, Solevid, M. (2017). Politisering och polarisering i ett yrvaket informationssamhälle. Almedalen: SOM-institutet

Berndtsson J, Bjereld, U and Ydén, K. (2017). Tillbaka till framtiden? Svenskarnas syn på försvaret, värnplikten och NATO. In: Andersson, A, Ohlsson, J, Oscarsson, H and Oskarson, M (eds) Larmar och gör sig till. SOM-undersökningen 2017. SOM-rapport nr 70. Göteborg: SOM-institutet

Brooks DJ, Valentino BA (2011) A war of one's own: understanding the gender gap in support for war. Public Opin Q 75(2):270-286

Butt S, Byman D (2020) Right-wing extremism: the Russian connection. Survival 62(2):137-152

Campbell R, Erzeel S (2018) Exploring gender differences in support for rightist parties: the role of party and gender ideology. Polit Gend 14(1):80-105

Coffé H (2018) Gender and the radical right. The Oxford handbook of the radical right. Oxford University Press, New York, pp 200-211

Demker, M., and Odmalm, P. (2021). From governmental success to governmental breakdown: how a new dimension of conflict tore apart the politics of migration of the Swedish centre-right. Journal of Ethnic and Migration Studies, 1-16.

Demker, Marie (2017). Ökat motstånd mot flyktingmottagning och invandrares religionsfrihet. In: Andersson, A, Ohlsson, J, Oscarsson, H and Oskarson, M (eds) Larmar och gör sig till. SOMundersökningen 2017. SOM-rapport nr 70. Göteborg: SOM-institutet

Duina F, Carson D (2020) Not so right after all? making sense of the progressive rhetoric of Europe's farright parties. Int Sociol 35(1):3-21

Eichenberg RC (2003) Gender differences in public attitudes toward the use of force by the United States, 1990-2003. Int Secur 28(1):110-141

Eichenberg RC (2019) Gender, war, and world order: a study of public opinion. Cornell University Press, New York

Eichenberg RC, Read BM (2016) Gender difference in attitudes towards global issues. The origins of gender difference in personal security dispositions. Polit Psychol. https://doi.org/10.1111/pops.12748

Eichenberg, R. C., Lizotte, M. K., and Stoll, R. J. Forthcoming (2021). Socialized to safety?

Vestin Erik. (2017). Utbildningsinriktning, partival och politiska attityder över generationerna. In: Andersson, A, Ohlsson, J, Oscarsson, H and Oskarson, M (eds) Larmar och gör sig till. SOM-undersökningen 2017. SOM-rapport nr 70. Göteborg: SOM-institutet

Farris SR (2017) In the name of women's rights. Duke University Press

Feinstein Y (2017) The rise and decline of "gender gaps" in support for military action: United States, 1986-2011. Polit Gend 13(4):618-655

Feldman S (2003) Enforcing social conformity: a theory of authoritarianism. Polit Psychol 24(1):41-74

Fernquist, J., Kaati, K., Pelzer, B., Asplund Cohen, K and Akrami, N. (2020). Hope, Cope, Rope. FOI Memo 7040

Flood M, Dragiewicz M, Pease B (2021) Resistance and backlash to gender equality. Aust J Soc Issues 56(3):393-408

Grzebalska, Weronika and Petö, Andrea. (2018). The gendered modus operandi of the illiberal transformation in Hungary and Poland. In: Women's Studies International Forum. Pergamon, p. 164-172. Gustafsod, Per E. 1998. Gender Differences in risk perception: Theoretical and methodological erspectives. Risk Analysis 18(6):805-811

Gustafsod PE (1998) Gender Differences in risk perception: Theoretical and methodological erspectives. Risk Anal 18(6):805-811 
Helmus, Todd C., et al. (2018). Russian social media influence: Understanding Russian propaganda in Eastern Europe. Rand Corporation, 2018. Available at: www.rand.org/content/dam/rand/pubs/resea rch_reports/RR2200/RR2237/RAND_RR2237.pdf.

Hetherington M, Suhay E (2011) Authoritarianism, threat, and Americans' support for the war on terror. Am J Polit Sci 55(3):546-560

Holm M (2019) The rise of online counterpublics?: the limits of inclusion in a digital age. Uppsala University, Uppsala

Hovden JF, Mjelde H (2019) Increasingly controversial, cultural, and political: the immigration debate in Scandinavian newspapers 1970-2016. Javnost Public 26(2):138-157

Huddy L, Feldman S, Capelos T, Provost C (2002) The consequences of terrorism: disentangling the effects of personal and national threat. Polit Psychol 23(3):485-509

Huddy L, Feldman S, Taber C, Lahav G (2005) Threat, anxiety, and support of antiterrorism policies. Am J Political Sci 49(3):593-608

Innes M, Innes H, Roberts C, Harmston D, Grinnell D (2021) The normalisation and domestication of digital disinformation: on the alignment and consequences of far-right and Russian State (dis) information operations andcampaigns in Europe. J Cyber Policy 6(1):31-49

Johansson T (2014) Maskuliniteter i Förändring (Bilaga 3, SOU 2014:6). Fritzes offentliga publikationer, Stockholm

Keskinen S (2013) Antifeminism and white identity politics. Nord J Migr Res 3(4):225

Korolczuk E, Graff A (2018) Gender as "Ebola from Brussels": the anticolonial frame and the rise of illiberal populism. Signs J Women Culture Soc 43(4):797-821

Krzyżanowski M (2018a) "We are a small country that has done enormously lot": the 'refugee crisis' and the hybrid discourse of politicizing immigration in Sweden. J Immigr Refug Stud 16(1-2):97-117

Lizotte MK (2019) Investigating the origins of the gender gap in support for war. Polit Stud Rev 17(2):124-135

Lombardo E, Kantola J (2019) European integration and disintegration: feminist perspectives on inequalities and social justice. JCMS J Common Market Stud 57(1):62-76

Martinsson, Johan. and Andersson, Ulrika. (2019). Swedish trends 1986-2018. Retrieved from https:// som.gu.se/digitalAssets/1732/1732590_7.-swedish-trends-1986-2018.pdf. file://C:/Users/s-9064/ Downloads/7.\%20Swedish\%20trends\%20(1986-2019)_v3.pdf

Merolla JL, Zechmeister EJ (2009) Democracy at risk: how terrorist threats affect the public. University of Chicago Press, Chicago, IL

Mulinari D, Neergaard A (2014) We are Sweden democrats because we care for others: exploring racisms in the Swedish extreme right. Eur J Women's Stud 21(1):43-56

Nilsson, J (2019) Internet source retrieved 2020-11-25, https://mk-mk.facebook.com/jonas.o.e.nilsson/ videos/is-terrorister-feminism-och-v\%C3\%A5r-s\%C3\%A4kerhet/2331180286893360/)

Norocel OC, Saresma T, Lähdesmäki T, Ruotsalainen M (2020) Discursive constructions of white Nordicmasculinities in right-wing populist media. Men Masculinities 23(3-4):425-446

Perrin A (2005) National threat and political culture: authoritarianism, antiauthoritarianism, and the September 11 attacks. Polit Psychol 26:167-194

Rhine S, Smithey SI, and Haynes A (1994). Cross-national differences in political attitudes: the effects of gender in Canada. In: annual meeting of the midwest political science association, Chicago, IL

Robinson F (2021) Feminist foreign policy as ethical foreign policy? a care ethics perspective. J Int Polit Theory 17(1):20-37

Rydgren J (ed) (2018) The Oxford handbook of the radical right. Oxford University Press, Oxford

Sager M, Mulinari D (2018) Safety for whom? exploring femonationalism and care-racism in Sweden. Women's Stud Int Forum 68:149-156

Säkerhetspolisen (2020) https://www.sakerhetspolisen.se/download/18.4ffee9b31787cb4eddc36f/16221 05064669/sakerhetspolisens_arsbok_2020.pdf

Spierings N, Zaslove A (2015) Gendering the vote for populist radical-right parties. Patterns Prejudice 49(1-2):135-162

Spierings N, Lubbers M, Zaslove A (2017) 'Sexually modern nativist voters': do they exist and do they vote for the populist radical right? Gend Educ 29(2):216-237

Towns A, Karlsson E, Eyre J (2014) The equality conundrum: Gender and nation in the ideology of the SwedenDemocrats. Party Politics 20(2):237-247

Verloo M, Paternotte D (2018) The feminist project under threat in Europe. Polit Gov 6(3):1-5

Wagner W, Herranz-Surrallés A, Kaarbo J, Ostermann F (2018) Party politics at the water's edge: contestation of military operations in Europe. Eur Polit Sci Rev 10(4):537-563 
Wagnsson C, Olsson E-K, Nilsen I (2020) Gendered views in a feminist state: Swedish opinions on crime, terrorism, and national security. Gender Soc 34(5):790-817. https://doi.org/10.1177/08912 43220946029

Weiss, Andrew. S. (2020). With friends like these: the Kremlin's Far-right and populist connections in Italy and Austria. Carnegie Endowment for International Peace

Wodak R (2015) The politics of fear: what right-wing populist discourses mean. Sage, London

Wojczewski T (2020) 'Enemies of the people': populism and the politics of (in) security. Eur J Int Sec $5(1): 5-24$

Publisher's Note Springer Nature remains neutral with regard to jurisdictional claims in published maps and institutional affiliations. 